18. Fiske $\mathrm{CH}$, Subbarow $\mathrm{Y} 1925$ The colorimetric determination of phosphorous. J Biol Chem 66:375-400

19. Clutter W, Bier DM, Shah SD, Cryer PE 1980 Epinephrine plasma metabolic clearance rates and physiologic thresholds for metabolic and hemodynamic actions in man. $\mathrm{J}$ Clin Invest 66:94-101

20. Munson P 1983 A computerized analysis of ligand binding data. Methods Enzymol 92:543-576

21. Tse J, Powell JR, Baste CA, Priest RE, Kuo JF 1979 Isoproterenol-induced cardiac hypertrophy: modifications in characteristics of $\beta$-adrenergic receptor, adenylate cyclase, and ventricular contraction. Endocrinology 105:246255

22. Vatner DE, Vatner SF, Nejima J, Uemura N, Susanni EE, Hintze TH, Homcy CJ 1989 Chronic norepinephrine elicits desensitization by uncoupling the $\beta$ receptor. J Clin Invest 84:1741-1748

23. DeBlasi A, Maisel AS, Feldman RD, Ziegler MG, Fratelli M, DiLallo M, Smith DA, Lai CC, Motulsky HJ 1986 In vivo regulation of beta-adrenergic receptors on human mononuclear leukocytes: assessment of receptor num- ber, location and function after posture change, exercise and isoproterenol infusion. J Clin Endocrinol Metab 63:847-853

24. Hayes JS, Pollock GD, Fuller RW 1984 In vivo cardiovascular responses to isoproterenol, dopamine and tyramine after prolonged infusion of isoproterenol. J Pharmacol Exp Ther 231:633-638

25. Brodde O-E, â Brinkman M, Schemuth, O'Hara N, Daul A 1985 Terbutalineinduced desensitization of human lymphocyte beta $_{2}$-adrenoreceptors. J Clin Invest 76:1096-1101

26. Feldman RD, Limbird JE, Nadeau J, FitzGerald A, Robertson D, Wood AJJ 1983 Dynamic regulation of leukocyte beta adrenergic receptor-agonist interactions by physiological changes in circulating catecholamines. J Clin Invest 72:164-170

27. Newnham JP, Lam RW, Hobel CJ, Padbury JF, Polk DH, Fisher DA 1986 Differential response of ovine placental lactogen levels in maternal and fetal circulations following single umbilical artery ligation in fetal sheep. Placenta 7:51-64

28. Bassett JM, Weeding CM, Hanson C 1990 Desensitization of $\beta$-receptor mediated responses to epinephrine in fetal lambs by prolonged ritodrine administration. Pediatr Res 28:388-390

\title{
Announcement
}

\section{NIH Treatment Study for Sydenham's Chorea}

Acutely ill patients with Sydenham's chorea are being sought for a controlled treatment study. Eligible patients will receive free diagnostic evaluation and treatment, including palliative medications, at the Child Psychiatry Branch of the National Institute of Mental Health in Bethesda, MD. The treatment study is an outgrowth of our long-term investigations of the sequelae of Sydenham's chorea. To participate, children should be at least 6 years old and acutely ill. There will be no expense to the patient (all treatment, travel, and lodging will be free of cost) and no remuneration. To refer a patient, contact Dr. Susan Swedo at (301) 496-6081, Building 10, Room 6N240, 9000 Rockville Pike, Bethesda, MD 20892, FAX (301) 402-0296. 